\title{
3D seismic imaging of buried Younger Dryas mass movement flows: Lake Windermere, UK
}

\author{
Mark E. Vardy a,*, Luke J.W. Pinson a , Jonathan M. Bull ${ }^{a}$, Justin K. Dix ${ }^{\text {a }}$, Timothy J. Henstock ${ }^{a}$, \\ John W. Davis ${ }^{a}$, Martin Gutowski ${ }^{b}$ \\ a National Oceanography Centre, Southampton, School of Ocean and Earth Science, University of Southampton, European Way, Southampton, SO14 3ZH, UK \\ b GeoAcoustics Ltd, Gapton Hall Industrial Estate, Great Yarmouth, NR31 ONQ, UK
}

\section{A R T I C L E I N F O}

\section{Article history:}

Received 13 October 2009

Received in revised form 26 December 2009

Accepted 29 December 2009

Available online $\mathrm{xxxx}$

\section{Keywords:}

High-resolution 3D seismic

Submarine landslides

Younger Dryas

Lake District

Windermere

Debris flows

Mass flows

Chirp

\begin{abstract}
A B S T R A C T
Windermere is a glacially overdeepened lake located in the southeastern Lake District, UK. Using the threedimensional (3D) Chirp subbottom profiler, we image mass movement deposits related to the Younger Dryas (YD) within a decimetre-resolution 3D seismic volume, documenting their internal structure and interaction with preexisting deposits in unprecedented detail. Three distinct flow events are identified and mapped throughout the 3D survey area. Package structures and seismic attributes classify them as: a small (total volume of c. $1500 \mathrm{~m}^{3}$ ) debris flow containing deformed translated blocks; a large (inferred total volume of c. $500,000 \mathrm{~m}^{3}$ ), homogeneous fine-grained mass flow deposit; and a debris flow (inferred total volume of c. $60,000 \mathrm{~m}^{3}$ ) containing small $($ c. $8.0 \times 2.0 \mathrm{~m}$ ) deformed translated blocks. Geomorphological mapping of their distribution and interaction with preexisting sediments permit the reconstruction of a depositional history for the stratigraphic units identified in the seismic volume.
\end{abstract}

Crown Copyright @ 2010 Published by Elsevier B.V. All rights reserved.

\section{Introduction}

Mass movements of partly consolidated sediments are common features in lacustrine, fjord, and marine environments, playing an important role in the redistribution of sediments from shallow to deep water (Hampton et al., 1996). Whilst initial studies were generally confined to the mapping of preserved events uplifted onshore (e.g., Farrell, 1984; Martinsen and Bakken, 1990), in recent years studies that have combined core logging and geophysical techniques have proliferated. Due to their extremely high hazard, most of this work has concentrated on large- to medium-scale structures originating on active (e.g., Tappin et al., 2007) and passive (e.g., Micallef et al., 2009) continental margins; and the end-member turbidite flows channelled down submarine canyons (e.g., Lykousis et al., 2007). While several large submarine landslides have been imaged offshore using traditional 3D seismic methods (e.g., Frey-Martinez et al., 2005; Gee et al., 2006; Bull et al., 2009), studies of small- to medium-scale structures in fjord or lacustrine settings are limited to interpretation from irregularly distributed cores (e.g., Guyard et al., 2007), sparse two-

\footnotetext{
* Corresponding author. Tel.: + 442380596666.

E-mail address: mev@noc.soton.ac.uk (M.E. Vardy).
}

dimensional (2D) seismic lines (50-100 m line spacing) (e.g., Schnellmann et al., 2002), and/or their surface expression in swath/ side-scan sonar imagery (e.g., Canals et al., 2004; Ilstad et al., 2004).

In lacustrine environments, such surveys have permitted the correlation between contemporaneous mass movement events and paleoseismic records or anthropogenic influences (e.g., Schnellmann et al., 2002; Monecke et al., 2006; Schnellmann et al., 2006) but only limited interpretation of slide morphology (Schnellmann et al., 2005). In the offshore environment, 3D seismic data sets have bridged the gap between localised core stratigraphy and regional 2D seismic lines, allowing mass movement deposits to be structurally mapped in great detail (e.g., Frey-Martinez et al., 2005). From this, a welldeveloped set of indicators for flow direction and deposition process has been proposed (Bull et al., 2009). However, the lack of similar 3D data sets in fjord and lacustrine environments has made it unclear whether the same methods can be applied in these locations or at smaller scales.

Here we present the results of a decimetre-resolution 3D seismic survey over the proximal/headwall domain of mass movement deposits in the north basin of Windermere, UK, which are Younger Dryas (YD) in age. Three distinct flow deposits are identified and mapped through the volume. Differences in their acoustic character (base/top reflector amplitudes and internal structure), overall morphology (deposit shape, top and base reflector structure), and remote 
acoustic properties (acoustic quality factor, Q) are used to classify them as two debris flows and one larger mass flow. Flow direction is inferred using variation in package thickness, and the long-axis alignment of deformed translated blocks.

\section{Background and methodology}

Windermere, the largest lake in the English Lake District, stretches c. $17 \mathrm{~km}$ in a curve running from NNW to SSW and narrows from c. $1.5 \mathrm{~km}$-wide in the north to $<0.5 \mathrm{~km}$ at the southern tip (Fig. 1). Forming the southeastern spoke of a radial drainage pattern overdeepened by successive glaciations, Windermere is a classic fjord-type lake with steep valley margins and sharp lower breaks of slope. Situated c. $35 \mathrm{~m}$ above sea level (asl), Windermere is dammed at the southern end by a bedrock sill 21 m above the present lake level, which forces the lake to drain westward down the narrow (c. $250 \mathrm{~m}$ wide) and shallow ( $<2 \mathrm{~m}$ below present lake level) Leven valley (Wilson, 1987).

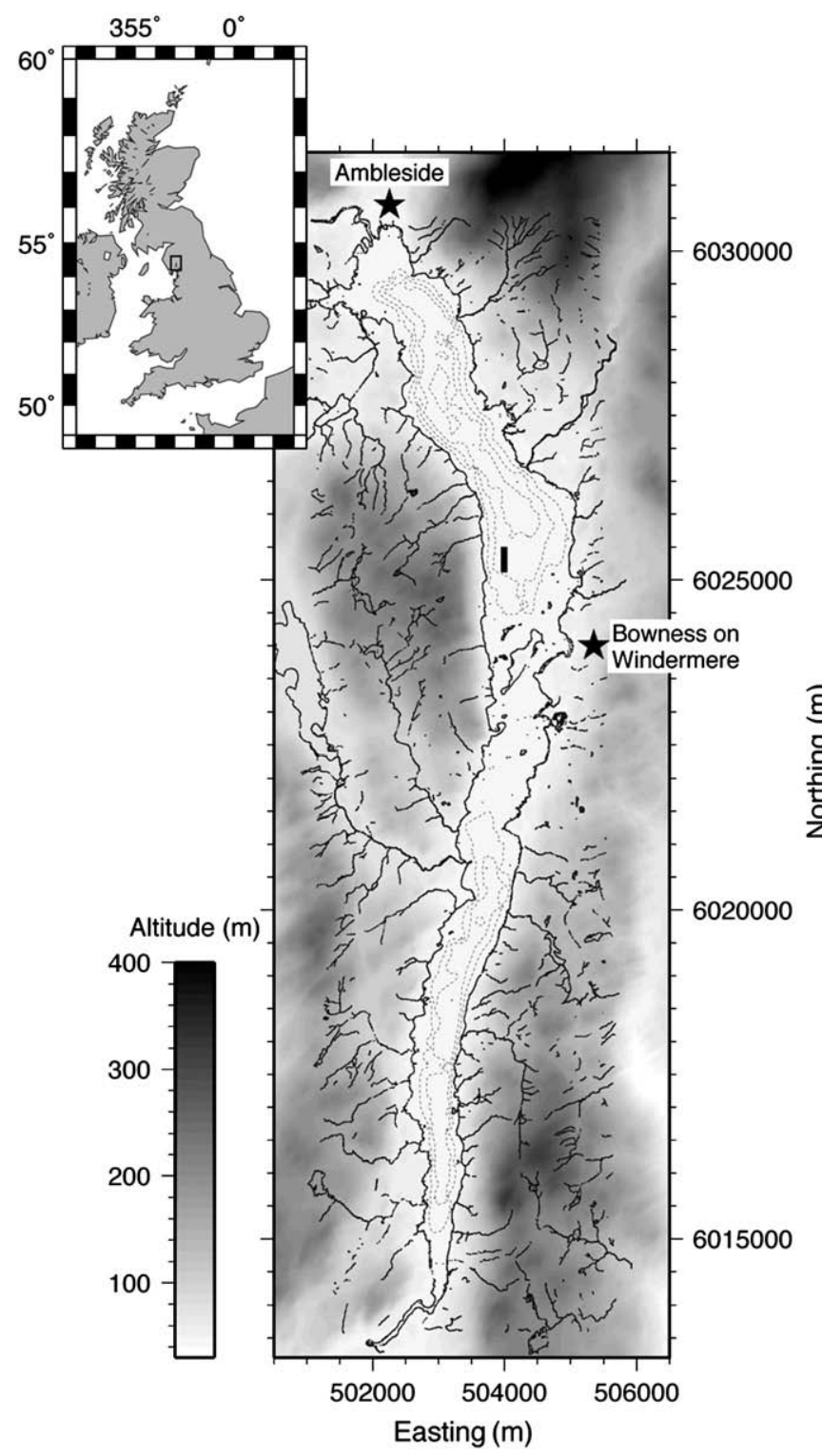

Fig. 1. Location map showing surrounding topography as shaded grayscale; outline of lake and surrounding waterways as black lines; lake bathymetry contours at 15,30 , and $45 \mathrm{~m}$ as dashed grey lines; and two nearby towns. Black box in the northern basin delimits location of 3D Chirp survey.

\subsection{Regional background}

At the Last Glacial Maximum (LGM) of the British and Irish ice sheet (BIIS) (c. 30-25 ka BP; Bradwell et al., 2008), snowblown, wet-based glaciers extended throughout the English Lake District (thought to be $>800$-m-thick in some locations; Ballantyne et al., 2009). BIIS retreat lead to complete deglaciation of the Lake District, leaving a heavily eroded landscape of glacially overdeepened valleys and lakes crosscut by a series of well-preserved retreat structures and infilling finer sediments deposited during the Allerød (locally referred to as the Windermere Interstadial; WI) (17.1-12.9 ka BP; Lea et al., 2003; Lowe et al., 2008). During the YD (12.9-11.7 ka BP; Walker et al., 2009), glaciation in the English Lake District was not as extensive as in Scotland or northern Europe, permanently maintaining only plateau icefields bordered by small valley and cirque glaciers (the closest to Windermere being around Sca Fell; Sissons, 1980; McDougall, 2001). These glaciers did not extend as far south or east as Windermere (Fig. 1), thereby leaving the LGM and post-LGM sedimentary stratigraphy well-preserved.

Over $150 \mathrm{~km}$ of high-resolution multichannel seismic (MCS) data (acquired using a boomer source) provide a coarse grid (50-200 m spacing) of regional lines from which the LGM and post-LGM history has been reconstructed (Pinson, 2009). As illustrated in Fig. 2 using a north-south profile through the North Basin, correlation of these data with the extensive record of preexisting shallow cores (e.g., Pennington, 1943, 1975, 1978; Smith, 1959; Mackereth, 1971) allowed the definition of the five main facies summarised in Table 1 (Pinson, 2009).

This sequence of calibrated seismic facies illustrates a stratigraphy and morphology dominated by glacial processes. Glacial scouring left two overdeepened bedrock basins, subdivided into a series of sedimentary depocentres by retreat moraines (SSS I and II). These depocentres are infilled by thick ( $\geq 30 \mathrm{~m}$ ) fining upward deposits of outwash fines and overlain by Allerød deposits laid down after climate amelioration (SSS III). When glaciers readvanced in the higher catchment during the YD, these organic-rich deposits were buried beneath a layer of laminated clays, which shows evidence of subsequent localised mechanical reworking by mass movement events at the end of the YD (SSS IV). This has been followed by Holocene deposition of a thin (average $3.5 \mathrm{~m}$ ) layer of post-glacial mud that drapes over the late glacial stratigraphy (SSS V). Of the total sedimentary infill, $<20 \%$ by volume was deposited during the interstadial/interglacial periods, which lasted c. $16.0 \mathrm{ky}$; it is, instead, dominated by the short time period ( $<5 \mathrm{ky}$ ) of high deposition rates during ice sheet retreat from the LGM and the YD (Coope et al., 1977; Bowen et al., 2002; Lea et al., 2003).

Although, during the YD the maximum glacial extent was several kilometres NW of Windermere (Fig. 1), post-BIIS paraglacial activity is observed to have been extensive (Wilson, 2005; Wilson and Smith, 2006) and deglaciation affected lake sedimentary stratigraphy through localised reworking. Here we focus on these deposits (SSS IV), the distribution of which is illustrated in Fig. 3, surrounded by the slope of the regional topography. In the North Basin, two discrete areas with SSS IV deposits thicker than 3.75 m correlate with flows associated with the steep-sided western lake shore between $6,024,000$ and $6,026,500 \mathrm{~m}$ northing (A to $\mathrm{A}^{\prime}$; Fig. 3). The South Basin, however, has steep slopes $\left(>2^{\circ}\right)$ on both lake shores along almost the full length and correspondingly contains a large number of slope failure deposits, with thicknesses $>15.0 \mathrm{~m}$ in some locations. Stratigraphically, SSS IV comprises several independent mass movement deposits, indicating multiple events/ sources rather than a single cataclysmic event. This is taken to infer localised gravitational slope failure from/because of overloading on the steep lake margins by unconsolidated terrestrial sediment derived via runoff as the likely source.

\subsection{Methodology}

In January 2008 a decimetre-resolution 3D seismic volume over the more southerly YD flow deposit in the North Basin (Fig. 3) was 

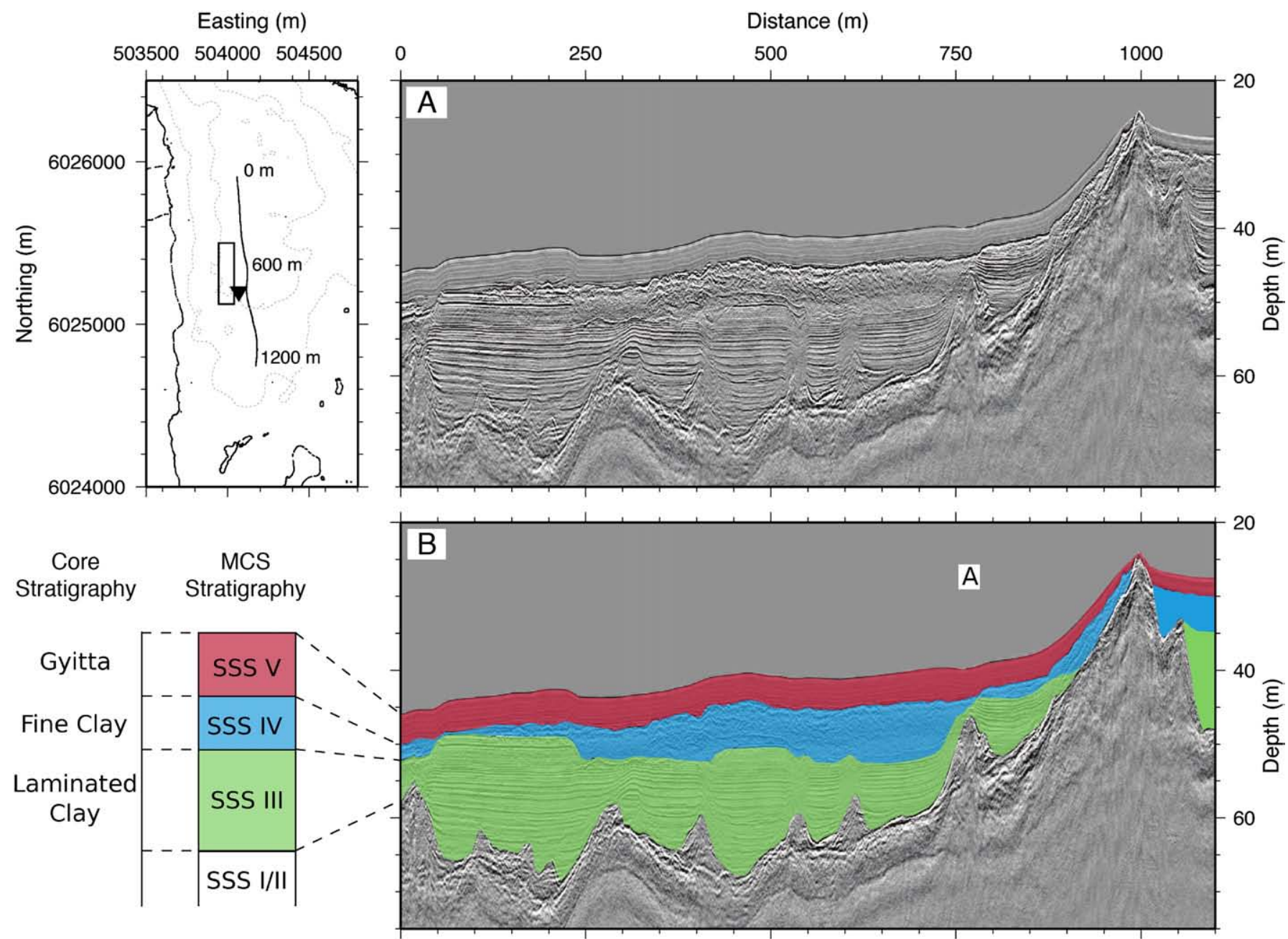

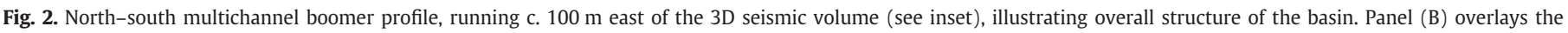

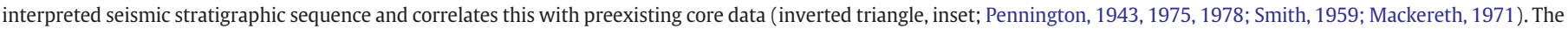
moraine labelled " $\mathrm{A}$ ", is the same east-west orientated moraine observed in the 3D seismic volume. This profile has been 2D prestack Kirchhoff depth migrated.

acquired using the 3D Chirp subbottom profiler (Fig. 3B). A $100 \times 400 \mathrm{~m}$ area situated $200 \mathrm{~m}$ from the western lake shore, was surveyed to cover the truncation of the deposit against the till valley

Table 1

Overview of five seismic facies identified in multichannel boomer data with approximate ages of deposition (Pinson, 2009).

\begin{tabular}{|c|c|c|}
\hline Facies & Description & Age (ka BP) \\
\hline SSS V & $\begin{array}{l}\text { Thin }(1.0-3.5 \mathrm{~m}) \text {, uniform drape of detrital Gyitta with } \\
20-25 \% \text { (dry weight) organic content (Pennington, 1975). }\end{array}$ & $0-11.7$ \\
\hline SSS IV & $\begin{array}{l}\text { Chaotic or chaotic-to-transparent seismic facies } \\
\text { of varying thickness ( }<1.0 \mathrm{~m} \text { up to } 10.0 \mathrm{~m} \text { ), bounded } \\
\text { by high amplitude top and, in places, bottom reflectors. } \\
\text { Where the base reflector is strong, the overall unit } \\
\text { morphology is indicative of this being the erosional } \\
\text { lower surface of a mass movement event reworking YD } \\
\text { sediments, scouring into preexisting strata and pinching } \\
\text { out further from the shore. }\end{array}$ & $11.7-12.9$ \\
\hline SSS III & $\begin{array}{l}\text { Thick (up to } 50 \mathrm{~m} \text { in the South and } 30 \mathrm{~m} \text { in the North } \\
\text { Basins) unit of Late Glacial glaciolacustrine infill and } \\
\text { subsequent Allerød lacustrine deposition. Identified in } \\
\text { cores as being finely varved ( } 2.0 \mathrm{~cm} \text { fining up to } 0.3 \mathrm{~cm} \text {; } \\
\text { Pennington, 1978) with low organic content. }\end{array}$ & $12.9-21.8$ \\
\hline SSS II & $\begin{array}{l}\text { Glaciofluvial outwash material found at some localities } \\
\text { in the bottom of both the North and South Basins. }\end{array}$ & $>17.6$ \\
\hline SSS I & $\begin{array}{l}\text { Outwash and lodgement till covering the ice-scoured } \\
\text { valley floor, exhibiting a distinct surface morphology } \\
\text { of LGM retreat moraines. }\end{array}$ & $>17.6$ \\
\hline
\end{tabular}

side. The 3D Chirp profiler is a rigid-framed, high-resolution subbottom profiler that records the reflected waveforms in true 3D at a temporal sample interval of $0.02 \mathrm{~ms}$ and horizontal sampling of $12.5 \times 12.5 \mathrm{~cm}$ (Bull et al., 2005; Vardy et al., 2008) (Table 2). More than 12 million traces were acquired over the $100 \times 400 \mathrm{~m}$ survey area, providing $83 f$ lakefloor was repeatedly covered.

The data demonstrated good signal-to-noise $(S / N)$ ratios (Fig. 4), allowing a simple processing flow concentrating on optimising the resolution through migration of the diffracted energy to the correct location. However, interpretation of the poorly imaged sediment/till interface was improved by combining coincident traces into a simple common midpoint stacked volume. Additionally, in the edges of the volume where trace numbers were lower, the $S / N$ of the sediment/till interface was further increased by applying an envelope function, which reduces vertical resolution but strengthens coherent reflectors.

\section{Results}

\subsection{Stratigraphic context}

The same gross stratigraphic framework interpreted from regional 2D lines (Pinson, 2009) can be identified within the decimetreresolution 3D seismic volume (Fig. 4A and B).

The sediment/till interface (top of SSS I/II and bottom of SSS III) is inferred by changes in the acoustic character and reflector termination, mapped using a combination of stacked and migrated volumes. 


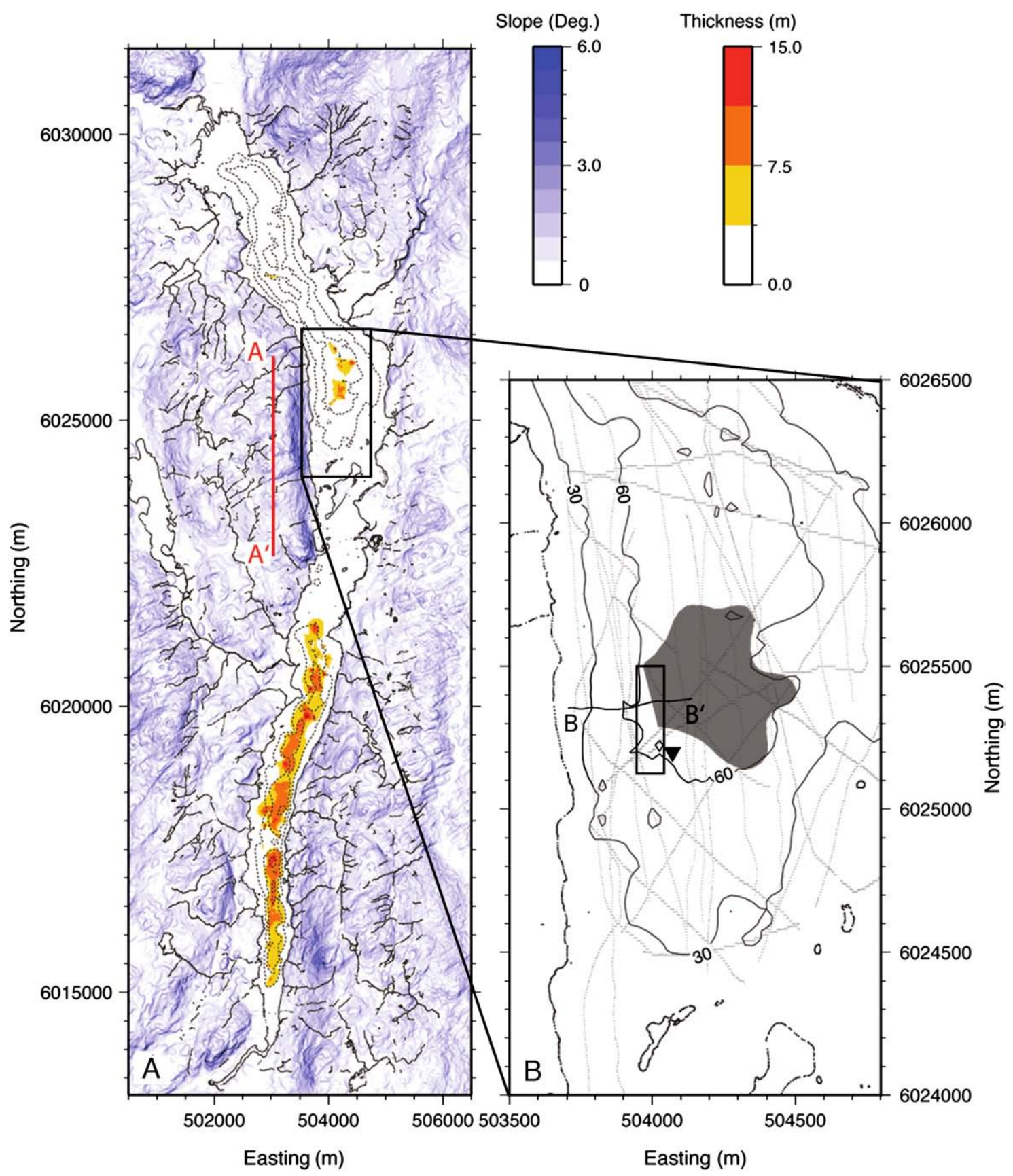

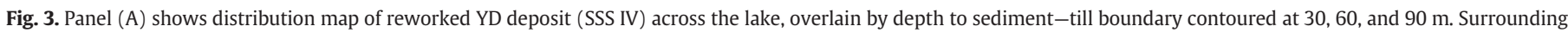

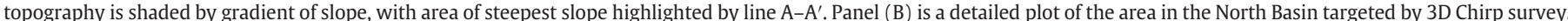

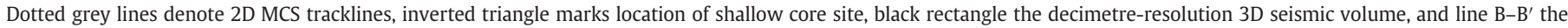
location of shore-tie line in Fig. 8. Shaded grey region indicates limit of target mass movement deposit mapped using regional MCS lines.

Overlaying this, the cyclical internal reflectors of the Late Glacial SSS III extend beyond the bottom of the migrated volume ( $60 \mathrm{~m}$ depth below present lake level) at the western and northern extents of the

Table 2

Overview of 3D Chirp subbottom profiler.

\begin{tabular}{|c|c|c|c|c|c|}
\hline Source & $\begin{array}{l}\text { No. } \\
\text { receivers }\end{array}$ & Bin size & $\begin{array}{l}\text { Sampling } \\
\text { interval }\end{array}$ & $\begin{array}{l}\text { Positioning } \\
\text { accuracy }\end{array}$ & Pulse rate \\
\hline $\begin{array}{l}4 \text { Chirp } \\
\text { Transducers } \\
(1.5-13.0 \mathrm{kHz})\end{array}$ & 60 & $12.5 \mathrm{~cm}$ & $0.02 \mathrm{~ms}$ & $\begin{array}{l}X= \pm 0.46 \mathrm{~cm} \\
Y= \pm 0.70 \mathrm{~cm} \\
Z= \pm 1.82 \mathrm{~cm}\end{array}$ & $4 s^{-1}$ \\
\hline
\end{tabular}

area, attaining maximum thicknesses of $>13.0 \mathrm{~m}$. The base of this unit shows a general southward and westward shallowing trend, along with a number of localised highs. The east-west-oriented moraine observed in the MCS data (labelled A; Figs. 2 and 5) defines the limit of a smaller (c. 80-m-wide) depocentre in the southern third of the volume. While, a further moraine (B; Fig. 5), rising to c. $48 \mathrm{~m}$ below present lake level, c. $100 \mathrm{~m}$ north divides the rest of the survey area into two depocentres (Fig. 5). This northerly moraine is not observed farther out in the basin, suggesting that east of the study area these two depocentres merge into the main North Basin depocentre.

This divides the volume into three geographically separate depocentres (hitherto referred to as southern, middle, and northern; Fig. 5), each of which is infilled by SSS III with no evidence for 
A

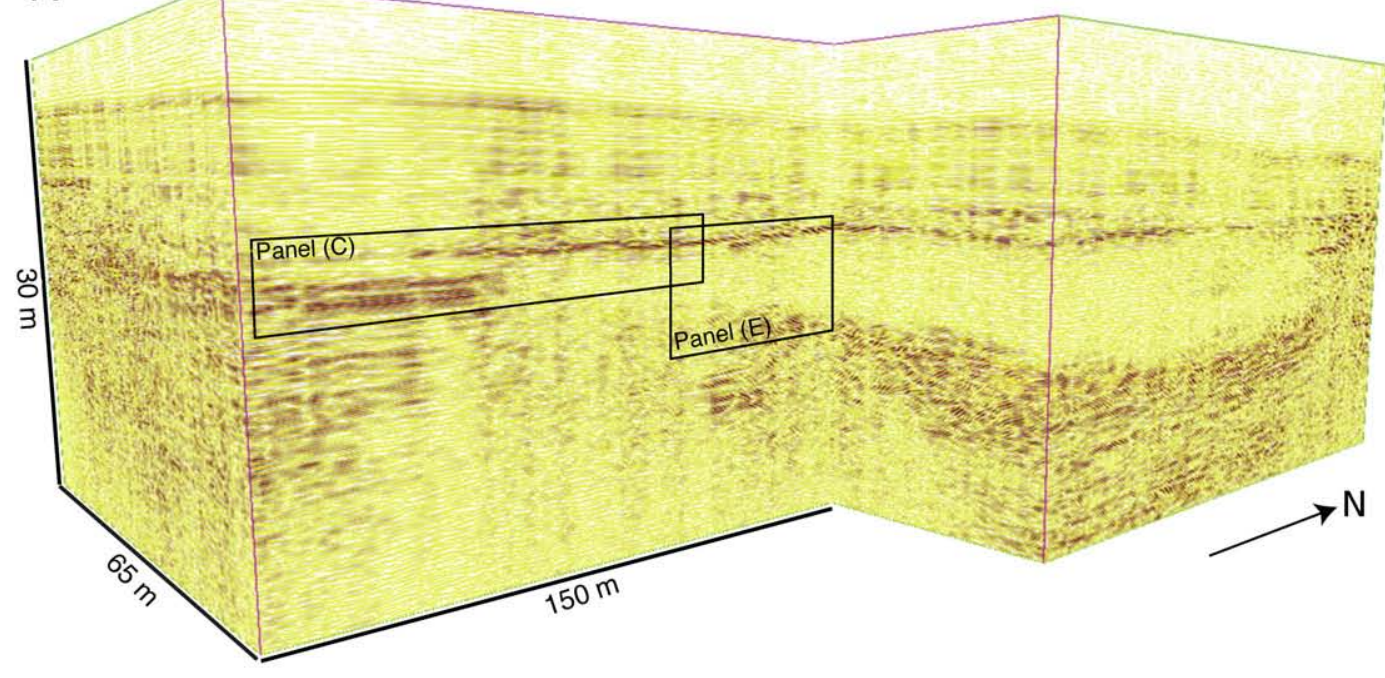

B

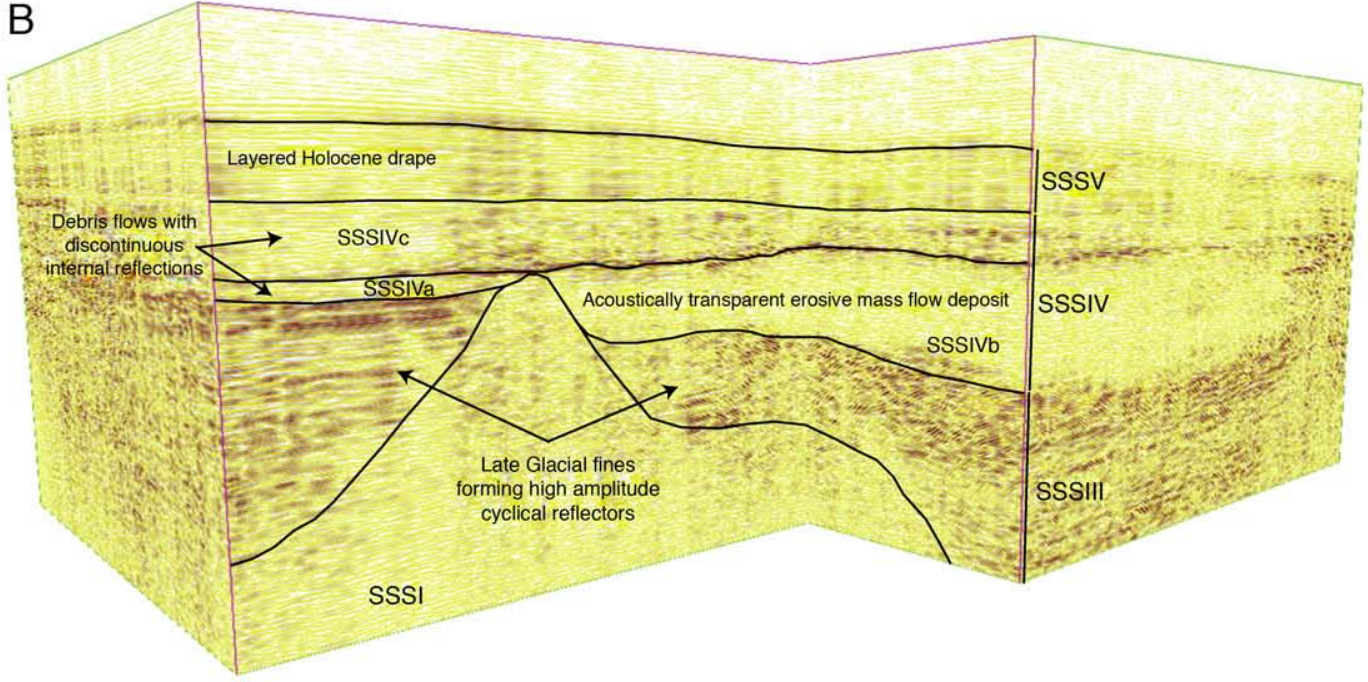

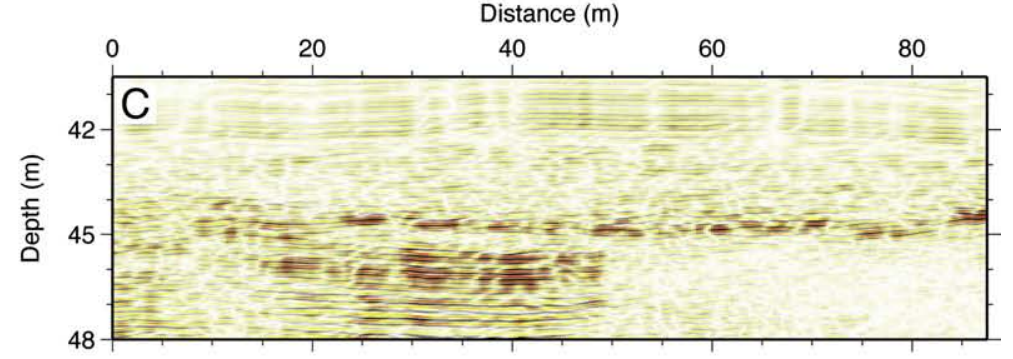

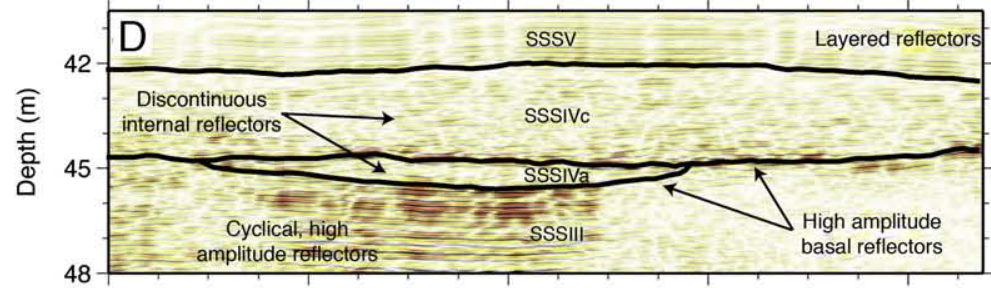

衰
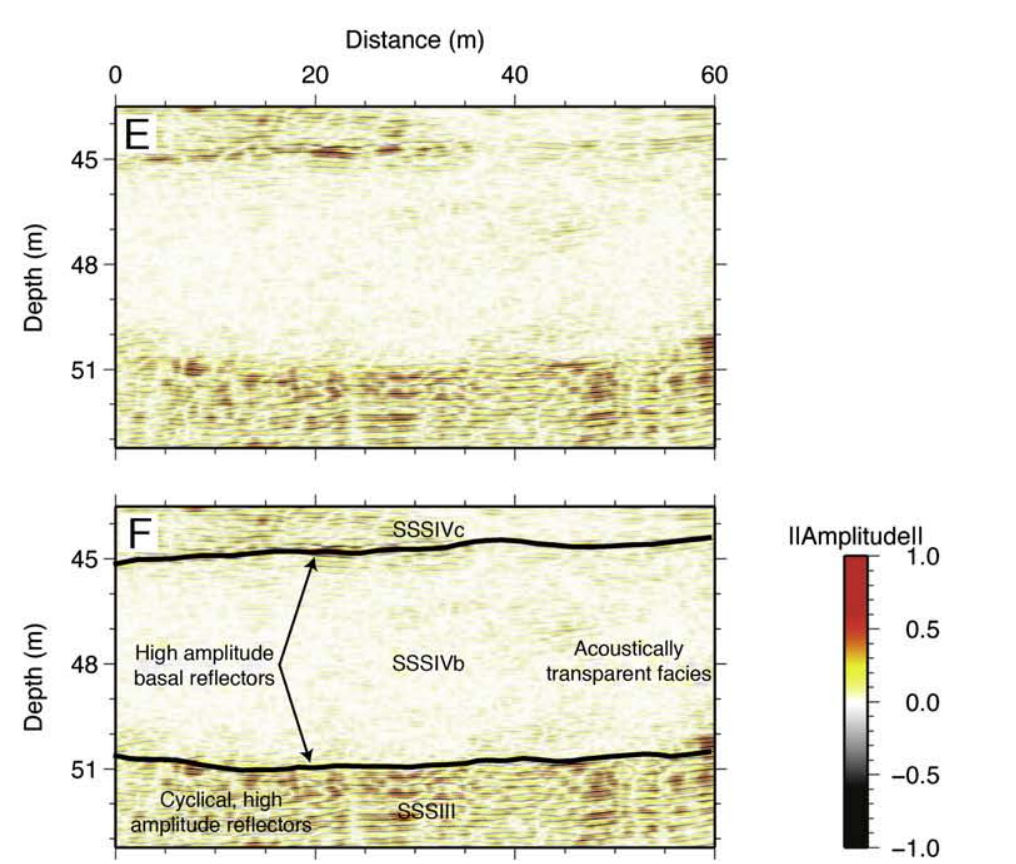

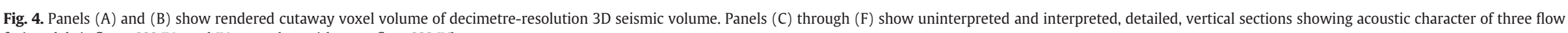
facies; debris flows SSS IVa and IVc, together with mass flow SSS IVb. 

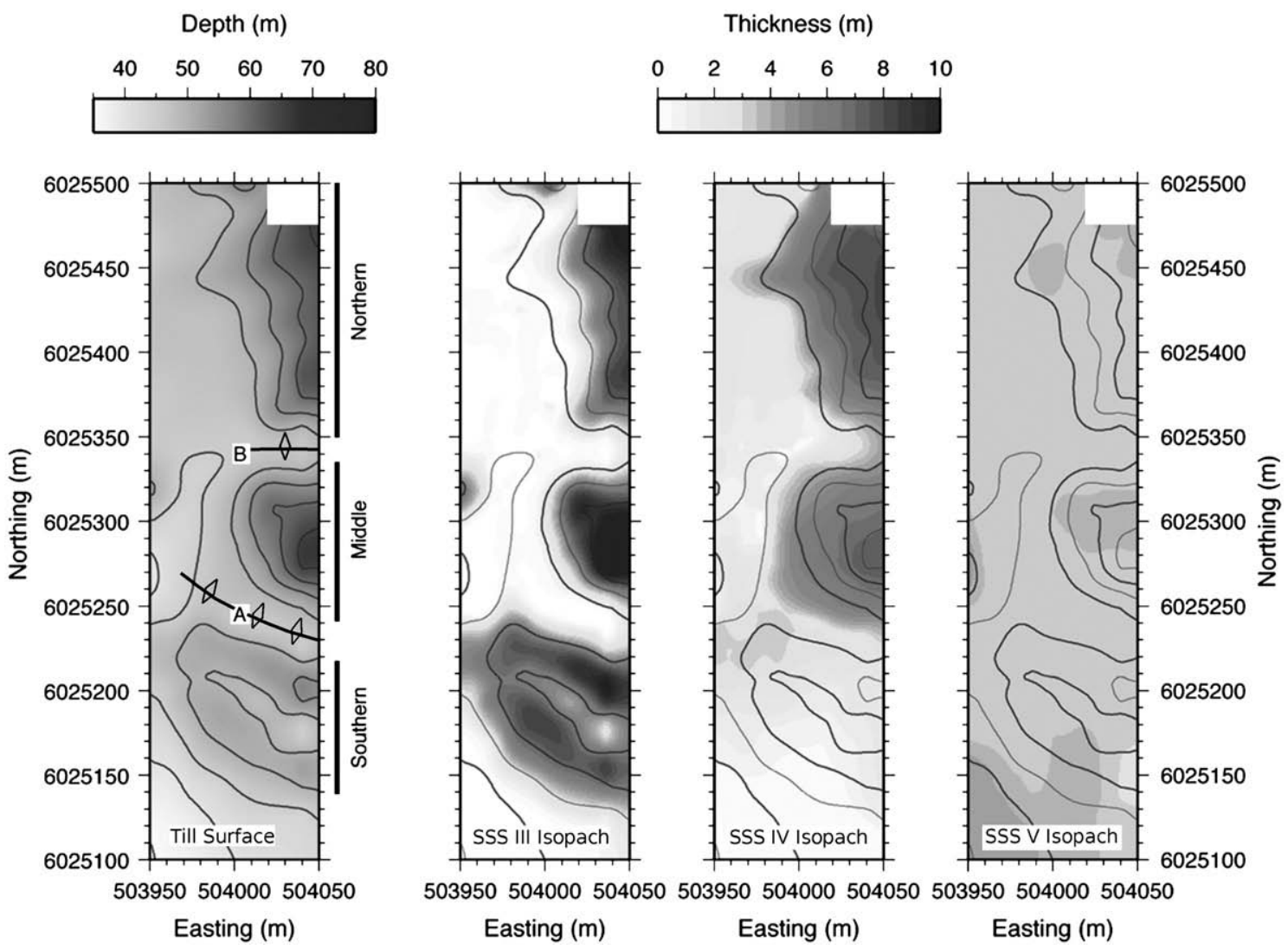

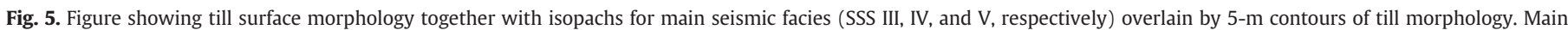

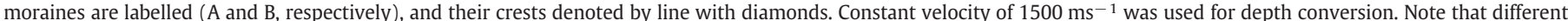
greyscale palettes are used for depth to till surface and isopach maps.

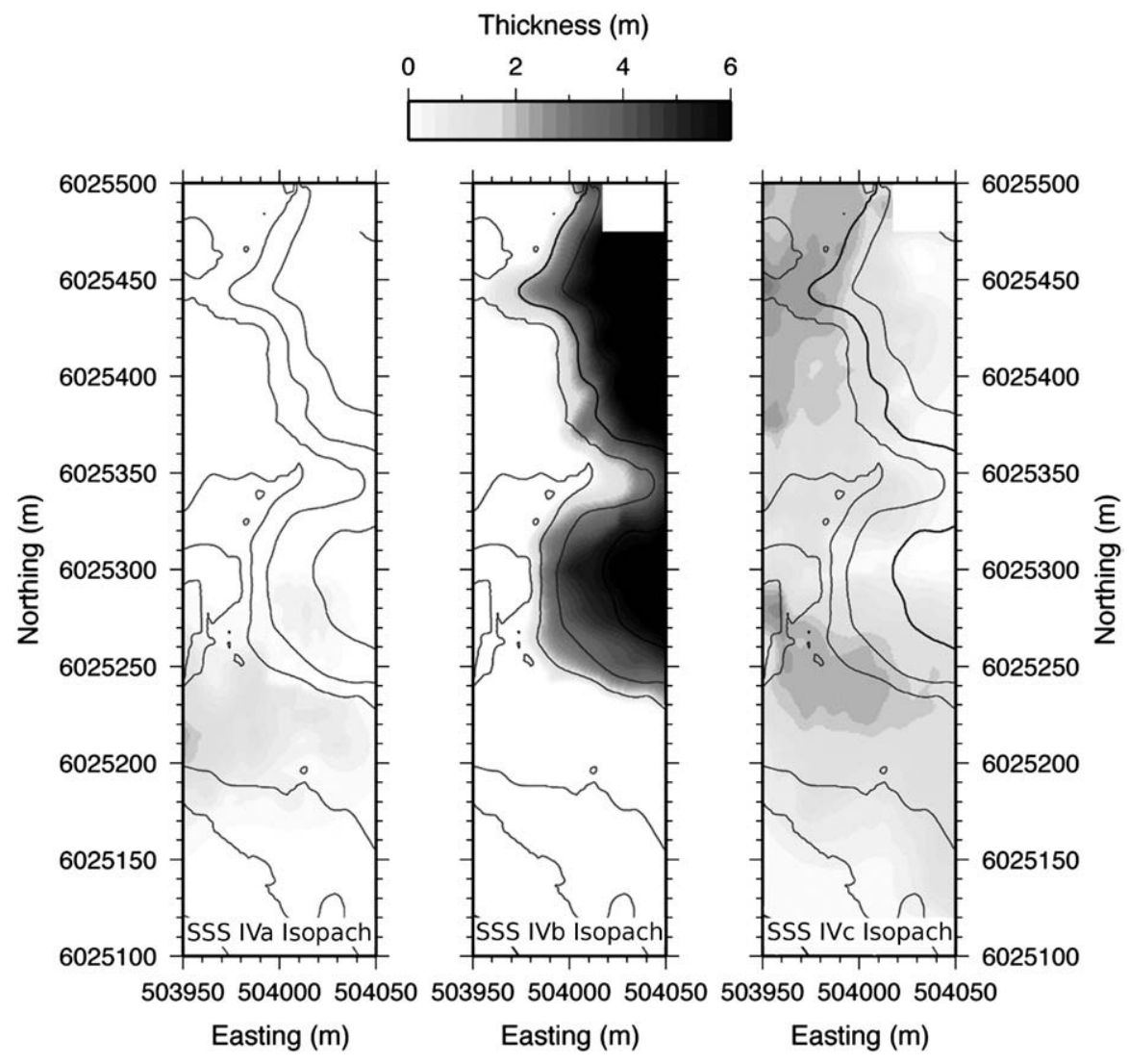

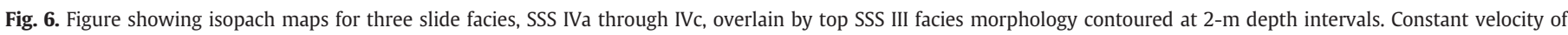
$1500 \mathrm{~ms}^{-1}$ was used for depth conversion. 
Table 3

Overview of properties for slide deposits SSS IVa through IVc. Physical dimensions are provided, along with details of internal seismic structure, and interpreted deposition regime.

\begin{tabular}{|c|c|c|c|c|c|}
\hline Facies & $\begin{array}{l}\text { Volume } \\
\text { in study } \\
\text { area }\left(\mathrm{m}^{3}\right)\end{array}$ & $\begin{array}{l}\text { Estimated } \\
\text { total volume } \\
\left(\mathrm{m}^{3}\right)\end{array}$ & $\begin{array}{l}\text { Internal } \\
\text { seismic } \\
\text { structure }\end{array}$ & $\begin{array}{l}\text { Flow } \\
\text { direction }\end{array}$ & $\begin{array}{l}\text { Deposition } \\
\text { regime }\end{array}$ \\
\hline IVc & 43,000 & 60,000 & Chaotic & North-east & Debris flow \\
\hline $\mathrm{IVb}$ & 54,000 & 500,000 & Transparent & North-east & Mass flow \\
\hline IVa & 1500 & - & Chaotic & East & Debris flow \\
\hline
\end{tabular}

extensive Late Glacial deposition on top of the moraines. All three SSS III depocentres are overlain by an eastward and northeastward thickening (up to c. $8 \mathrm{~m}$ ) unit consistent with the regionally identified YD slope failure deposit, SSS IV. Over the northern two depocentres, the facies is thickest (c. $8 \mathrm{~m}$ in the north and c. $7 \mathrm{~m}$ in the middle), and demonstrates the chaotic-to-transparent seismic facies with high amplitude base reflections, characteristic of subaqueous mass movement deposition (Mulder and Cochonat, 1996; Schnellmann et al., 2005). The unit thins rapidly to the south and west, pinching out completely to the south, with maximum southward extent of c. $6,025,186 \mathrm{~m}$ northing. While the unit thickness is controlled by underlying till morphology, the upper boundary of the facies shows little structuredeepening from 40 to $47 \mathrm{~m}$ at a shallow angle (c. $1.5^{\circ}$ ) to the north and northeast.

A thin (c. $3.5 \mathrm{~m}$ ) drape consistent with the Holocene deposited SSS V covers the whole volume. The lakebed dips at a shallow angle of c. $1.5^{\circ}$ to the north and northeast, deepening from c. 36 to $44 \mathrm{~m}$. Across the entire survey area the thickness of this package is highly uniform, varying less than $0.2 \mathrm{~m}$, and demonstrating a consistent sequence of seven subparallel internal reflectors.

\subsection{SSS IV}

The primary target of the volume was imaging of the mass movement deposits identified as being contemporaneous with the YD; SSS IV. The higher vertical resolution and 3D structural interpretation afforded by the 3D Chirp subbottom profiler allows several distinct subunits to be identified within this facies (Fig. 6). Remaining consistent to the existing stratigraphic sequence definitions, these are defined below and summarised in Table 3.

IVa. A small (c. $1500 \mathrm{~m}^{3}$ ), thin $(<1 \mathrm{~m})$ deposit observed in the southern depocentre and southwestern slope of the middle depocentre as two distinct deposits (Fig. 6) that thin rapidly to the NE. It has very high amplitude, incoherent top, and internal reflectors. Where it overlies SSS III in the southern depocentre, it has a high amplitude base reflector that is interpreted as being an erosional interface. In the middle depocentre, it sits directly on the till surface and demonstrates no clear basal reflector. Root mean squared (RMS) amplitudes extracted between the top and bottom reflectors of a seismic stratigraphic package provide an estimate of the amount of heterogeneity within the unit. A map of this seismic attribute for SSS IVa (Fig. 7) shows a high degree of variability, with several distinct high amplitude anomalies. These correspond to localised, continuous reflectors c. $0.5 \mathrm{~m}$ above the package base.

IVb. A large volume, chaotic-to-transparent seismic facies that overlays the northern and middle depocentres. Throughout the 3D survey area it demonstrates no change in the internal seismic structure, which suggests a consistent flow fabric (Fig. 7). Where the unit is not incised by overlying slide deposits, the upper reflector is weak and chaotic, while the base reflector is high amplitude but irregular. It is split by the moraine B at

II Amplitude ||

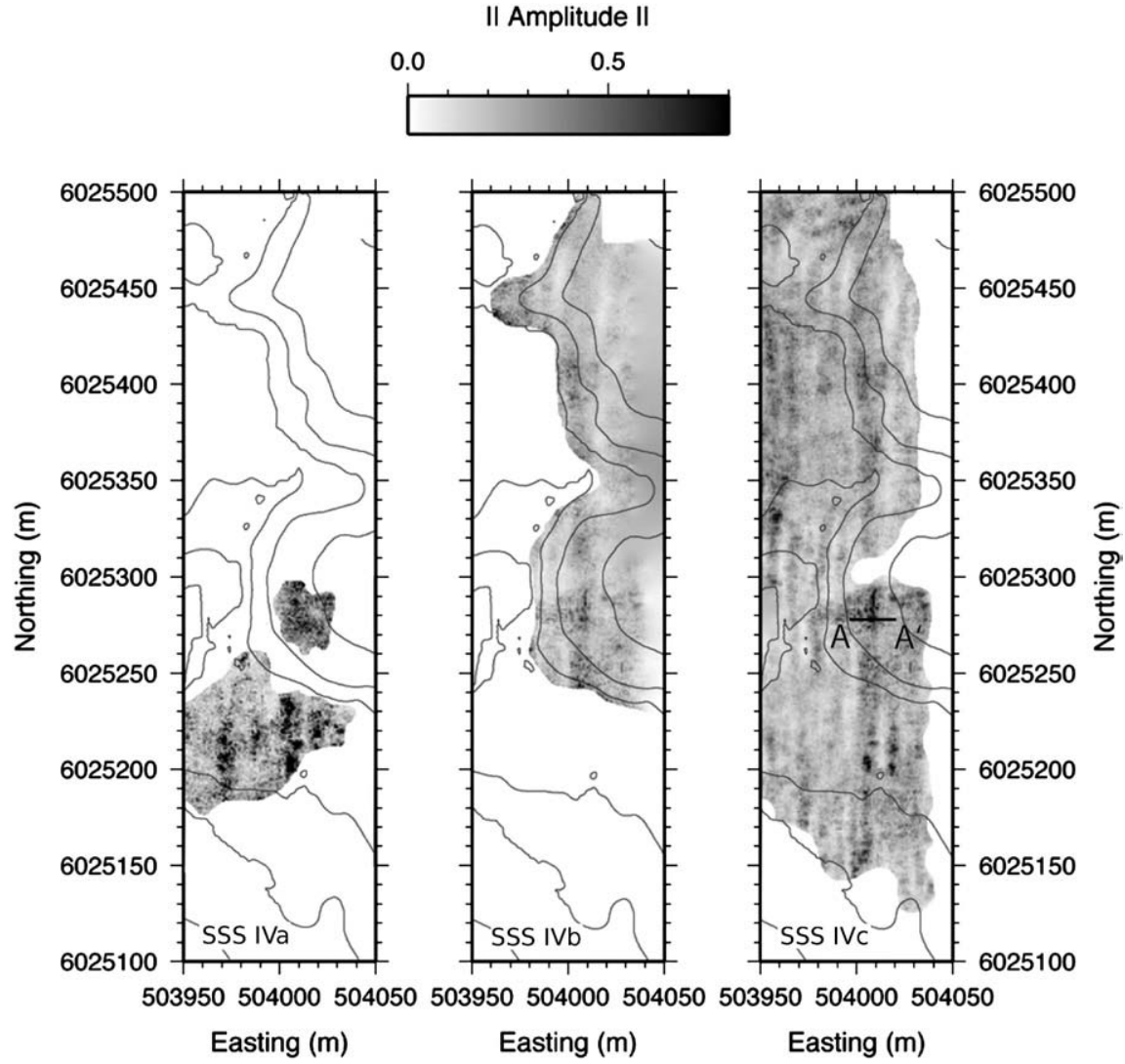

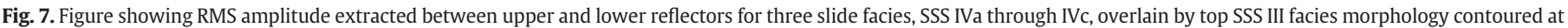

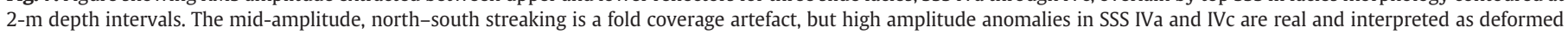
translated blocks. Profile A to $\mathrm{A}^{\prime}$ is shown in Fig. 9. 
c. $6,025,340 \mathrm{~m}$ northing, creating two thicker deposits of c. 8.0 and c. $6.5 \mathrm{~m}$ (northern and middle depocentres, respectively), joined by a thin drape (up to $2.5 \mathrm{~m}$ ). The facies thins rapidly to the south and west, pinching out against the (inferred) sediment/till interface at dip angles of c. $16^{\circ}$. The total volume of this subunit within the volume is c. $54,000 \mathrm{~m}^{3}$, thickening to the north and northeast (maximum thickness c. $8 \mathrm{~m}$ ), extending beyond the limits of the survey area. In addition, the same facies can be tracked a large distance into the North Basin using the regional MCS lines (Fig. 3) where it clearly incises into the preexisting sediment fill (to a maximum depth of c. $4 \mathrm{~m}$ ), covering an estimated area of c. $130,300 \mathrm{~m}^{2}$ with a total volume of c. $500,000 \mathrm{~m}^{3}$ (average thickness c. $3.8 \mathrm{~m}$ ).

IVc. A chaotic seismic facies (c. $43,000 \mathrm{~m}^{3}$ ) with similar appearance to SSS IVa, bounded by a high amplitude base reflector and a discontinuous, low amplitude upper. Similar to SSS IVb, the unit is concentrated in the middle and northern depocentres, with maximum thicknesses of c. 3.1 and c. $2.4 \mathrm{~m}$ (north and middle, respectively), but also extends as a thin $(<1.5 \mathrm{~m})$ layer farther south and west. Covering c. $75 \%$ of the survey area, this facies pinches out to the south at c. 6,025,186 m northing. The package is typically lens shaped, thinning gradually northward and eastward with very little relief on the top and bottom reflectors $\left(<2^{\circ}\right)$, although there are localised discontinuities in the top. Total volume of the facies within the 3D survey area (c. $43,000 \mathrm{~m}^{3}$ ) is similar to SSS IVb because, although thinner, it covers a greater area. However, this facies does not appear as far out into the basin; extending only a short distance to the east where it is sampled in a core (Pennington, 1943) and MCS line (Fig. 2; Pinson, 2009), before pinching out. This suggests a much smaller total volume of c. $60,000 \mathrm{~m}^{3}$ for the deposit.

\section{Discussion}

Mulder and Cochonat (1996) defined a classification scheme for submarine mass movement deposits (summarised in Table 4) based on material cohesion and plasticity/turbulence of flow during deposition. Using remote methods, these flow mechanisms can be differentiated based upon: overall deposit morphology; top/base reflector morphology; coherence/incoherence of preserved internal structure; along with deformation and/or scouring of preexisting sedimentary facies.

\subsection{SSS IVa}

The SSS IVa package is of limited extent, with only the distal part of the deposit imaged in the 3D seismic area (Fig. 6). It forms two

Table 4

Overview of mass movement deposit classification scheme (after Mulder and Cochonat, 1996).

\begin{tabular}{|c|c|c|c|}
\hline Major group & Minor-group & Sub-group & Observed structure \\
\hline \multirow{3}{*}{$\begin{array}{l}\text { Mass slide } \\
\text { (cohesive } \\
\text { structure) }\end{array}$} & Creeping & - & $\begin{array}{l}\text {-No failure surface } \\
\text {-Low deformation }\end{array}$ \\
\hline & $\begin{array}{l}\text { Block or slab } \\
\text { rock avalanche }\end{array}$ & - & $\begin{array}{l}\text {-Isolated decimetre- to } \\
\text { hectrometre-sized elements }\end{array}$ \\
\hline & Slide & - & $\begin{array}{l}\text {-Distinct failure surface } \\
\text {-Structure }>100 \mathrm{~m}\end{array}$ \\
\hline \multirow[t]{3}{*}{$\begin{array}{l}\text { Gravity flow } \\
\text { (incohesive } \\
\text { structure) }\end{array}$} & Mass flow & $\begin{array}{l}\text { Debris flow } \\
\text { Liquified flow }\end{array}$ & $\begin{array}{l}\text {-Motion supported by matrix } \\
\text {-Motion supported by fluid } \\
\text {-Fluid and sediment mixed }\end{array}$ \\
\hline & & $\begin{array}{l}\text { Fluidized } \\
\text { flow }\end{array}$ & -Motion supported by fluid \\
\hline & $\begin{array}{l}\text { Turbidity } \\
\text { current }\end{array}$ & Low density & $\begin{array}{l}\text {-Sediment "floats" in fluid layer } \\
\text {-Low density } \\
\text {-Fine deposits }\end{array}$ \\
\hline
\end{tabular}

discrete deposits that, although not directly connected, due to their geographic distribution are interpreted as being part of the same mass movement facies. The top reflector is highly discontinuous and irregular, while the base is high amplitude and erosional. This suggests a debris flow interpretation for SSS IVa, which is supported by the presence of deformed translated blocks (Fig. 7).

The long-axis orientation of these coherent blocks of material, transported downslope with the main debris flow or slide body, has previously been used to infer flow direction (Frey-Martinez et al., 2005; Gee et al., 2006). This implies a northeastward dominant flow direction, which is in agreement with the package thinning.

\subsection{SSS IVb}

Unlike SSS IVa, SSS IVb has been cored in a more distal setting (Pennington, 1943), identifying it as being minerogenic clays deposited during the YD. As a result, these facies are interpreted as being formed by the remobilisation of YD material, probably during or shortly after climate amelioration, triggered by the gravitational failure of unstable, unconsolidated slope material from overloading by increased land-derived runoff. This interpretation fits well with the seismic stratigraphy: high amplitude but irregular base reflector; rough high amplitude top reflector; and complete lack of internal structure. In addition, the depth of erosion (c. $4.0 \mathrm{~m}$ ) and distinct lateral package termination observed farther into the basin (Fig. 2) suggest a higher density, more laminar flow regime rather than a turbidity current (Mulder and Cochonat, 1996). This supports the assertion of a mass flow deposit with a high level of remoulding and no preservation of the preexisting internal structure (Mulder and Cochonat, 1996; Schnellmann et al., 2005).

The consistent flow fabric infers a single cataclysmic deposition event rather than multiple smaller flows. Using the method of Pinson et al. (2008) to estimate a seismic quality factor $(Q)$ using the broad bandwidth of the Chirp source sweep, also suggests a homogenous facies of very fine-grained, clay-based sediment $(Q=300 \pm 38)$. This agreement in flow composition inferred by stratigraphic character, $Q$ values extracted from the proximal region covered by the 3D seismic volume, and more distal cores, constrains the possible source mechanisms.

SSS IVb requires the remobilisation of a large amount (total volume c. $500,000 \mathrm{~m}^{3}$ ) of homogeneous, fine-grained sediment. A possible model for the formation of SSS IVb is the gravitational slope failure of a fine outwash drape deposited throughout the lake during glacial retreat at the end of the YD. In the northern part of the North Basin, where SSS IV shows no evidence of mechanical reworking, package thicknesses of c. $1.5 \mathrm{~m}$ are taken to be representative of this drape thickness (in keeping with outwash deposits observed in modern analogues, which can peak at c. $0.3 \mathrm{my}^{-1} 10.0 \mathrm{~km}$ from the glacier front; Gilbert and Crookshanks, 2008). Given the rapid climate amelioration at the end of the YD ( $<100$ years; Walker et al., 2009), this would have been highly unconsolidated and unstable on the steep (c. $16^{\circ}$; Fig. 8 ) lake slopes. Figure 8 shows a 440 $\mathrm{m}$-long tie line running perpendicular to the western shore through the 3D survey area. Pre-Holocene deposits above the LGM till (SSS I) have been completely evacuated from the lake marginal slope, with only a small amount remaining very high up near the shore (shaded dark grey; Fig. 8). This is consistent with gravitational slope failure as a source. The slope region (c. $200,000 \mathrm{~m}^{2}$ bounded by moraine A to the south and further moraines to the north) can account for c. $300,000 \mathrm{~m}^{3}$ of material, which, when combined with material remobilised from the present flow location, is consistent with the $500,000 \mathrm{~m}^{3}$ volume for SSS IVb. This source also agrees with the overall deposit distribution, which suggests a northeastward transport direction, bounded at its eastern limit by further moraines (Figs. 3B and 6). 


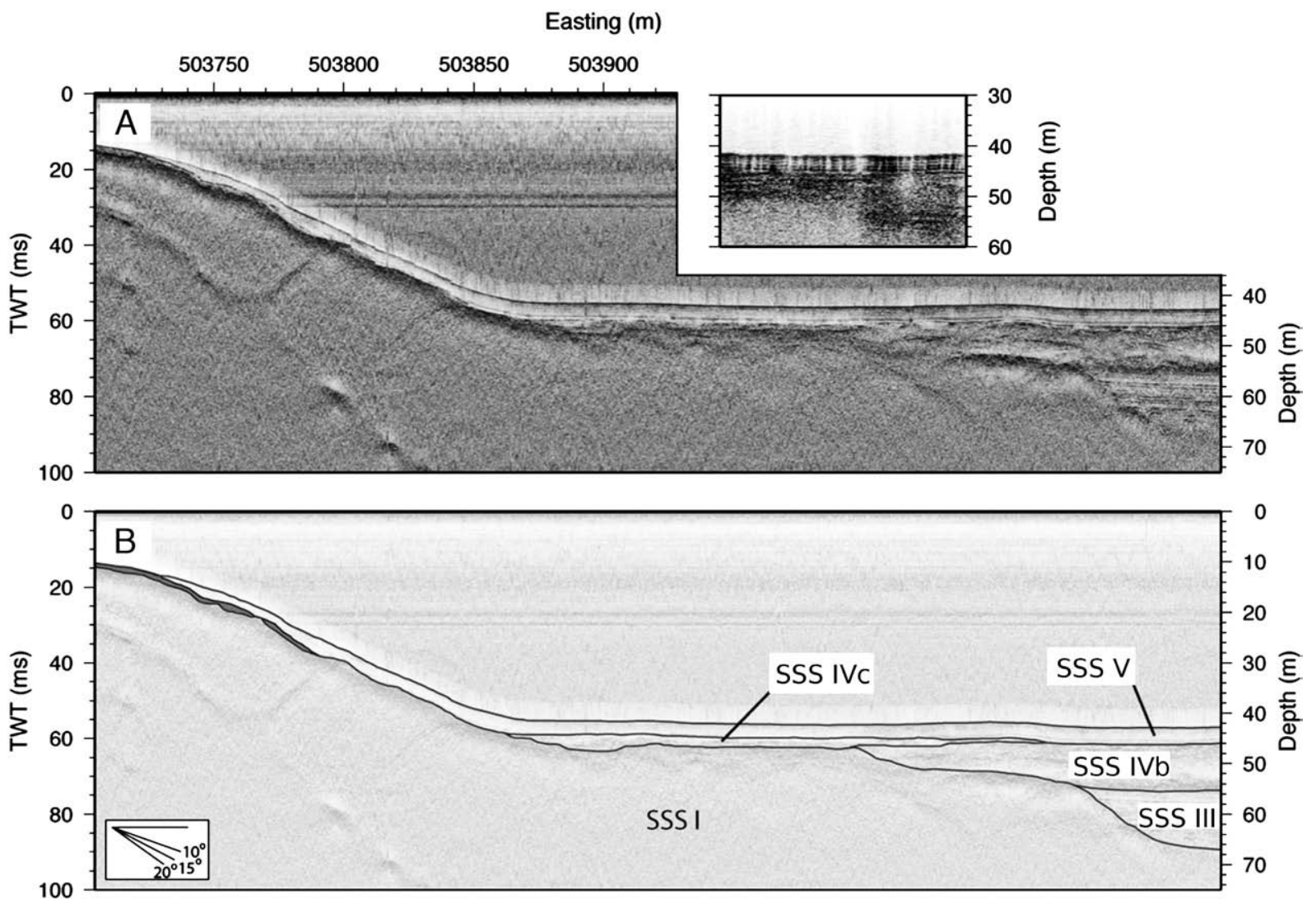

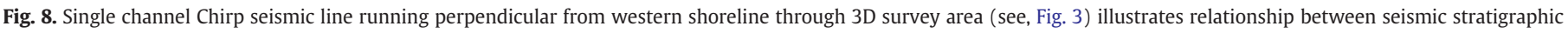

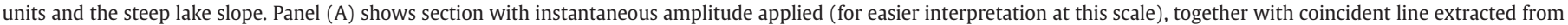
migrated 3D volume. Panel (B) shows interpretation.

\subsection{SSS IVC}

The seismic characteristics of a high amplitude, shear surface base reflector and discontinuous, chaotic internal structure suggest that the facies was formed by a debris flow (Mulder and Cochonat, 1996). This is in agreement with Pennington (1943) who sampled SSS IVc in the core due east of the survey area (Fig. 3B), describing it as a heavily deformed transition deposit of YD origin.

Within this unit a number of high amplitude, discrete reflectors (Fig. 7) show similar properties to those observed in SSS IVa. Fig. 9 shows a crossline section together with a timeslice from the migrated volume through one of these reflectors. There is a coherent c. $8.0 \times 2.0 \mathrm{~m}$

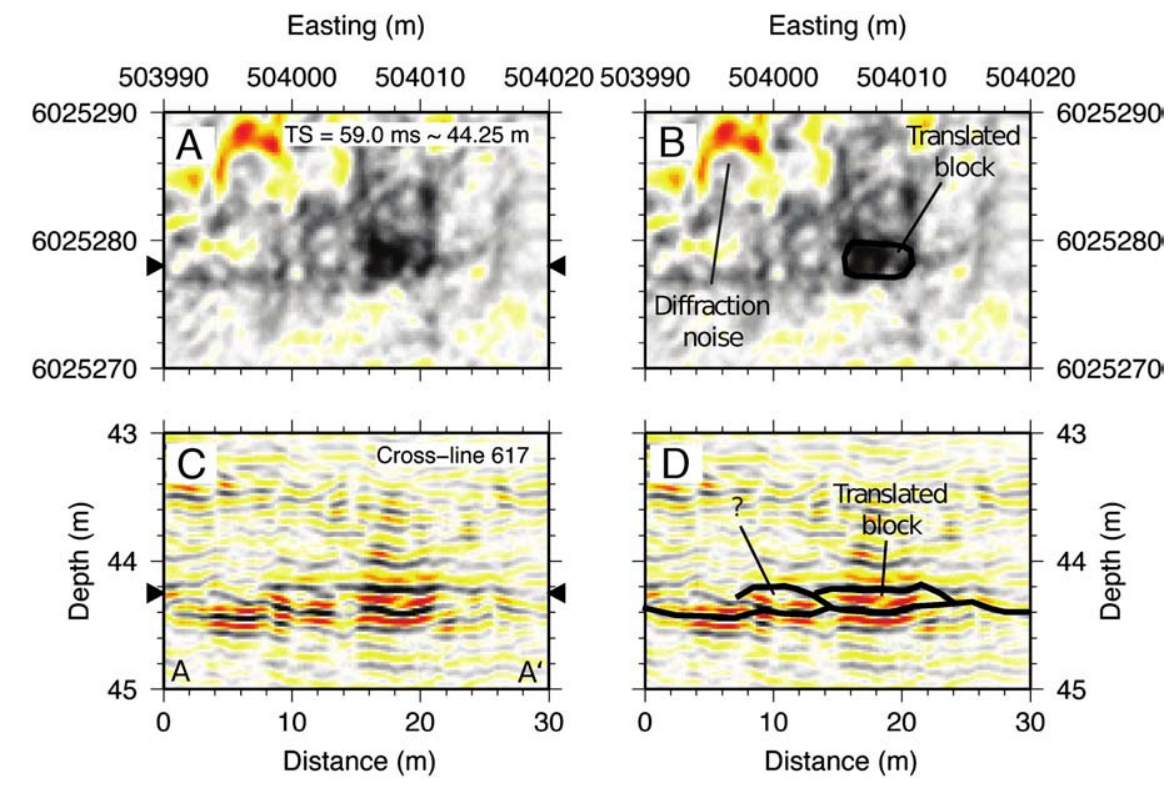

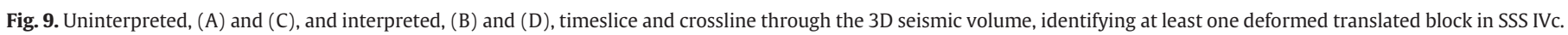
Similar structures are also seen in SSS IVa. Depth conversion performed using velocity of $1500 \mathrm{~ms}^{-1}$. 
polygonal high amplitude region, which shows up as a laterally coherent reflector c. $0.4 \mathrm{~m}$ above the facies base in the vertical section. This discrete region of coherency is in complete contrast to the surrounding chaotic reflectors of the facies and is interpreted as a translated deformed block. The block long-axis orientation can be used to infer flow direction (Bull et al., 2009), implying an eastward or westward direction of motion (Fig. 9). This agrees with the general eastward thinning of the unit (Fig. 6) and downslope direction, suggesting an eastward flow direction.

Similar structures observed on the Tampen slide (although on a completely different scale) are interpreted as deformed translated blocks (Frey-Martinez et al., 2005; Gee et al., 2006).

\section{Summary}

The acquisition of a decimetre-resolution 3D seismic volume through the headwall domain of a buried mass movement deposit has enabled identification of three discrete flow events. By mapping their distribution, reflector morphology, internal structure, and interaction with the preexisting and overlying sedimentary facies we have been able to classify them as two debris flows and one mass flow, thereby allowing the reconstruction of a depositional history for the stratigraphic units identified in the seismic volume (Fig. 10):

(i) The complicated morphology of outwash/lodgement till (SSS I/ II) and infilling thick (>13.0 m) deposit of fine-grained glacial, glaciolacustrine, and lacustrine deposits (SSS III)-left by the retreat of the BIIS and subsequent interstadial-was first reworked by a small (c. $1500 \mathrm{~m}^{3}$ ), localised debris flow moving in an easterly or northeasterly direction and transporting a number of deformed translated blocks (SSS IVa). This facies sits beneath the YD climate amelioration mass wasting deposits (SSS IVb and IVc) but above the Late Glacial fines (SSS III). Without core dating, it is impossible to accurately position this facies in a temporal framework, although its stratigraphic position supports slope failure deposition during the pulsed climatic changes at the beginning of the YD (e.g., Mayle et al., 1999).

(ii) The fast transition from stadial to interglacial conditions at the end of the YD resulted in the rapid deposition of a fine-grained

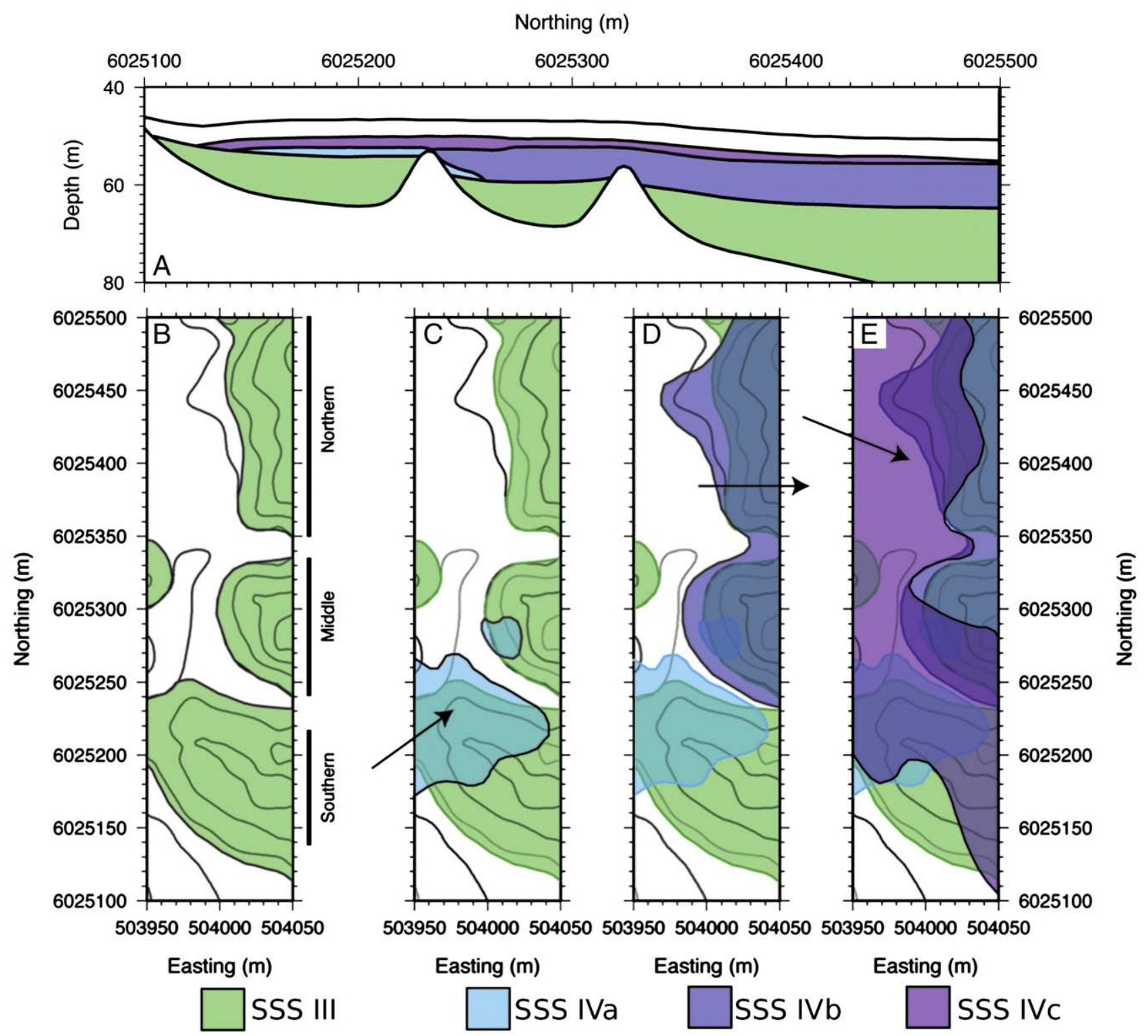

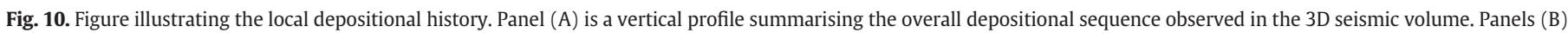
through (E) illustrate the spatial variation in deposition, with till surface contours sequentially overlain by sedimentary units SSS III, IVa, IVb, and IVc, respectively. 
drape of glacial outwash. Gravitation failure from overloading of this unconsolidated material on the steep lake slopes caused a single, large (imaged total volume c. $54,000 \mathrm{~m}^{3}$, inferred total volume c. $500,000 \mathrm{~m}^{3}$ ) erosive mass flow (SSS IVb) that scoured up to c. $4 \mathrm{~m}$ into preexisting sediments moving in a northeasterly direction. The flow is constrained to the south and east by moraines and demonstrates the distinct distal termination to the north/northeast classically associated with mass flow deposits. The material appears heavily reworked, with no preserved internal structure, and is observed consistently fine-grained in both distal and proximal samples.

(iii) SSS IVb was then incised by a smaller (imaged total volume c. $43,000 \mathrm{~m}^{3}$, inferred total volume c. $60,000 \mathrm{~m}^{3}$ ) debris flow (SSS IVc) moving in an easterly direction. Internal structure appears highly chaotic, with the exception of a number of small (c. $8.0 \times 2.0 \mathrm{~m}$ ) deformed translated blocks that were transported downslope with the main flow body. Core dating also defined this as remobilised YD stadial/interglacial transition material.

\section{Conclusions}

Interpretation of a decimetre-resolution 3D seismic volume over mass movement deposits related to the YD has allowed three distinct flow events to be mapped and classified based on their package structure and seismic attributes. They are identified as: (i) a small (c. $1500 \mathrm{~m}^{3}$ ) debris flow containing numerous small deformed translated blocks; (ii) a large (inferred total volume of c. 500,000 $\mathrm{m}^{3}$ ), consistently fine-grained mass flow deposit; and (iii) a smaller (inferred total volume of c. $60,000 \mathrm{~m}^{3}$ ) debris flow containing numerous small (c. $8.0 \times 2.0 \mathrm{~m}$ ) deformed translated blocks. Geomorphological mapping of their distribution and interaction with preexisting sediments has permitted the reconstruction of a depositional history for the stratigraphic units identified in the seismic volume.

With these data we have demonstrated the effectiveness of using decimetre-resolution 3D seismic volumes for the geomorphological interpretation of small-scale, shallow water mass movement deposits. By combining the detailed reflector and package morphology afforded by a true 3D seismic volume with quantitative seismic properties and preexisting core data, it has been possible to discern the deposition mechanism for these deposits and demonstrate the occurrence of comparable features to those observed on large-scale deposits. Further acquisition of similar 3D volumes over such easily accessible features can therefore improve our understanding of the formation of such structures on both small- and large-scales.

\section{Acknowledgements}

The authors wish to thank: the Engineering and Physical Sciences Research Council/Joint Grant Scheme (GR/R 12695/01) and GeoAcoustics Ltd for their help in developing the 3D Chirp subbottom profiler; Ben James for skippering the John Lund; along with Elizabeth Howarth, Michael Dobson, and Andrew Freeman from the Freshwater Biological Association (FBA), without whose help it would not have been possible to acquire these data. We would also like to acknowledge John Woodward for bringing the opportunities of the Lake District for Quaternary Science to our attention. In addition, we would like to thank the two anonymous reviewers and Richard Marston for their engaging and intuitive comments, together they had a significant impact on the quality of this manuscript.

\section{References}

Ballantyne, C., Stone, J., Fifield, L., 2009. Glaciation and deglaciation of the SW Lake District, England: implications of cosmogenic ${ }^{36} \mathrm{Cl}$ exposure dating. Proceedings of the Geologists' Association 120, 139-144.
Bowen, D., Phillips, F., McCabe, A., Knutz, P., Sykes, G., 2002. New data for the Last Glacial Maximum in Great Britain and Ireland. Quaternary Science Reviews 21, 89-101.

Bradwell, T., Stoker, M., Golledge, N., Wilson, C., Merritt, J., Long, D., Everest, J., Hestvik, O., Stevenson, A., Hubbard, A., Finlayson, A., Mathers, H., 2008. The northern sector of the last British Ice Sheet: maximum extent and demise. Earth Science Reviews $88,207-226$.

Bull, J., Gutowski, M., Dix, J., Henstock, T., Hogarth, P., Leighton, T., White, P., 2005. Design of a 3D Chirp sub-bottom imaging system. Marine Geophysical Researches 26, 157-169.

Bull, S., Cartwright, J., Huuse, M., 2009. A review of kinematic indicator from mass-transport complexes using 3D seismic data. Marine and Petroleum Geology 26, 1132-1151.

Canals, M., Lastras, G., Urgeles, R., Casamor, J., Mienert, J., Cattaneo, A., Batist, M.D., Haflidason, H., Imbo, Y., Laberg, J., Locat, J., Long, D., Longva, O., Masson, D., Sultan, N., Trincardi, F., Bryn, P., 2004. Slope failure dynamics and impacts from seafloor and shallow sub-seafloor geophysical data: case studies from the COSTA project. Marine Geology 213, 9-72.

Coope, G., Pennington, W., Mitchell, G., West, R., Morgan, A., Peacock, J., 1977. Fossil coleopteran assemblages as sensitive indicators of climatic changes during the Devensian (Last) Cold Stage [and Discussion]. Philosophical Transactions of the Royal Society of London. Series B. Biological Sciences 280, 313-340.

Farrell, S., 1984. A dislocated model applied to slump structures, Ainsa Basin, south central Pyrenees. Journal of Structural Geology 6, 727-736.

Frey-Martinez, J., Cartwright, J., Hall, B., 2005. 3D seismic interpretation of slump complexes: examples from the continental margin of Israel. Basin Research 17, 83-108.

Gee, M., Gawthorpe, R., Friedmann, S., 2006. Triggering and evolution of a giant landslide, offshore Angola revealed by 3D seismic stratigraphy and geomorphology. Journal of Sedimentary Research 76, 9-19.

Gilbert, R., Crookshanks, S., 2008. Sediment waves in a modern high-energy glacilacustrine environment. Sedimentology 56, 645-659.

Guyard, H., Chapron, E., St-Ogne, G., Anselmetti, F., Arnaud, F., Magand, O., Francus, P., Melieres, M.-A., 2007. High-altitude varve records of abrupt environmental changes and mining activity over the last 4000 years in the western French Alps (Lake Bramant, Grandes Rousses Massif). Quaternary Science Reviews 26, 2644-2660.

Hampton, M., Lee, H., Locat, J., 1996. Submarine landslides. Reviews of Geophysics 34, 33-59.

Ilstad, T., Blasio, F.D., Elverhoi, A., Harbitz, C., Engvik, L., Longva, O., Marr, J., 2004. On the frontal dynamics and morphology of submarine debris flows. Marine Geology 213, 481-497.

Lea, D., Pak, D., Peterson, L., Hughen, K., 2003. Temperatures over the Last Glacial Termination Synchroneity of tropical and high-latitude Atlantic. Science 301, 1361-1364.

Lowe, J., Rasmussen, S., Bjorck, S., Hoek, W., Steffensen, J., Walker, M., Yu, Z., 2008. Synchronisation of palaeoenvironmental events in the North Atlantic region during the Last Termination: a revised protocol recommended by the INTIMATE group. Quaternary Science Reviews 27 (1-2), 6-17.

Lykousis, V., Sakellariou, D., Locat, J., 2007. Submarine Mass Movements and Their Consequences: 3rd International Symposium. Springer.

Mackereth, F., 1971. On the variation in direction of the horizontal component of remnant magnetisation in lake sediments. Earth and Planetary Science Letters 12 , 332-338.

Martinsen, O., Bakken, B., 1990. Extensional and compressional zones in slumps and slides in the Namurian of County Clare, Ireland. Journal of the Geological Society of London 147, 153-164.

Mayle, F., Bell, M., Birks, H., Brooks, S., Coope, G., Lowe, J., Sheldrick, C., Shijie, L., Turner, C., Walker, M., 1999. Climate variations in Britain during the Last Glacial-Holocene transition (15.0-11.5 cal ka BP): comparison with the GRIP ice-core record. Journal of the Geological Society of London 156, 411-423.

McDougall, D., 2001. The geomorphological impact of Loch Lomond (Younger Dryas) stadial plateau icefields in the central Lake District, northwest England. Journal of Quaternary Science 16 (6), 531-543.

Micallef, A., Masson, D.G., Berndt, C., Stow, D., 2009. Development and mass movement processes of the north-eastern Storegga slide. Quaternary Science Reviews 28 (5-6), 433-448.

Monecke, K., Anselmetti, F., Becker, A., Schnellmann, M., Sturm, M., Giardini, D., 2006. Earthquake-induced deformation structures in lake deposits: a late Pleistocene to Holocene paleoseismic record for central Switzerland. Eclogae Geologicae Helvetiae 99 (3), 343-362.

Mulder, T., Cochonat, P., 1996. Classification of offshore mass movements. Journal of Sedimentary Research 66 (1), 43-57.

Pennington, W., 1943. Lake sediments: the bottom deposits of the north basin of Windermere, with special reference to the Diatom Succession. New Phytologist 42 (1), 1-27.

Pennington, W. 1975. Climatic changes in Britain, as interpreted from lake sediments, between 15,000 and 10,000 years ago. In: Horie, S. (Ed.), Paleolimnology of Lake Biwa and the Japanese Pleistocene, vol. 3. Publisher, Otsu, Japan, pp. 536-569.

Pennington, W., 1978. The origin of pollen in lake sediments: an enclosed lake compared with one receiving inflow streams. New Phytologist 83, 189-213.

Pinson, L., 2009. Remote classification of sediment properties using high-resolution marine seismic data. Ph.D. thesis, School of Ocean and Earth Science, University of Southampton, Southampton, UK.

Pinson, L., Henstock, T., Dix, J., Bull, J., 2008. Estimating quality factor and mean grain size of sediments from high-resolution marine seismic data. Geophysics 73 (4), G19-G28.

Schnellmann, M., Anselmetti, F., Giardini, D., McKenzie, J., 2005. Mass movementinduced fold- and thrust-belt structures in unconsolidated sediments in Lake Lucerne (Switzerland). Sedimentology 52 (271-289).

Schnellmann, M., Anselmetti, F., Giardini, D., McKenzie, J., 2006. 15, 000 Years of massmovement history in Lake Lucerne: implications for seismic and tsunami hazards. Eclogae Geologicae Helvetiae 99 (3), 409-428. 
Schnellmann, M., Anselmetti, F., Giardini, D., McKenzie, J., Ward, S., 2002. Prehistoric earthquake history revealed by lacustrine slump deposits. Geology 30 (12), 1131-1134. Sissons, J., 1980. The Loch Lomond Advance in the Lake District, northern England. Transactions of the Royal Society of Edinburgh: Earth Sciences 71, 13-27.

Smith, A., 1959. Structures in the stratified late-glacial clays of Windermere, England. Journal of Sedimentary Petrology 29, 447-453.

Tappin, D., McNeill, L., Henstock, T., Mosher, D., 2007. Mass wasting processes-offshore Sumatra. In: Lykousis, V., Sakellariou, D., Locat, J. (Eds.), Submarine Mass Movements and Their Consequences:3rd International Synposium of Advances in Natural and Technological Hazards, 27. Springer, Dordrecht, Netherlands, pp. 327-336.

Vardy, M., Dix, J., Henstock, T., Bull, J., Gutowski, M., 2008. Decimetre-resolution 3D seismic volume in shallow water: a case study in small object detection. Geophysics 73 (2), B33-B40.

Walker, M., Johnsen, S., Rasmussen, S., Popp, T., Steffensen, J.-P., Gibbard, P., Hoek, W. Lowe, J., Andrews, J., Bjorck, S., Cwynar, L., Hughen, K., Kershaw, P., Kromer, B., Litt, T., Lowe, D., Nakagawa, T., Newnham, R., Schwander, J., 2009. Formal definition and dating of the GSSP (Global Stratotype Section and Point) for the base of the Holocene using the Greenland NGRIP ice core, and selected auxiliary records. Journal of Quaternary Science 24 (1), 3-17.

Wilson, C., 1987. The outflow of Windermere, Cumbria: a re-appraisal. Geological Journal 22, 219-224.

Wilson, P., 2005. Paraglacial rock-slope failures in Wasdale, western Lake District England: morphology, styles, and significance. Proceedings of the Geologists Association 116, 349-361.

Wilson, P., Smith, A., 2006. Geomorphological characterisitcs and significance of Late Quaternary paraglacial rock-slope failures on Skiddaw Group terrain, Lake District, northwest England. Geographical Annalysis 88A (3), 237-252. 